\title{
Pengenalan dan Implementasi Konsep Digital Literacy dalam Kondisi BDR bagi Orang Tua Masa Kini
}

\author{
1) Ni Luh Putu Ning Septyarini Putri Astawa, ${ }^{2)}$ I Putu Cikal Taruna, ${ }^{3)}$ I Gede Putu Krisna Juliharta \\ ${ }^{1), 2), 3)}$ Sistem Informasi, STMIK Primakara \\ E-mail:ningseptyarini@ymail.com
}

\begin{abstract}
Article Info
Article History

Received: 2020-11-17

Revised: 2021-01-05

Published: 2021-01-13

Keywords:

Digital Literacy;

Learn from Home;

Parentin.

Abstract

Rapidly growing technological advances have an impact on everyday life. In this digital era, various kinds of knowledge could already be searched on the internet. With the current condition where the internet is no longer something expensive, of course it forces parents to follow the trends. Therefore, the purpose of this activity is to provide knowledge to parents of students about the understanding and implementation of Digital Literacy in learning from home learning conditions. This activity focuses on providing socialization about the importance of understanding and implementing mentoring children at home using technology. The methods used in this activity are lecture, simulation, and practice methods. The participants gave positive responses to this activity, which can be seen from the results of the questionnaire at the end of the training. Besides that, it can also be seen from the enthusiasm of the participants in the activity by actively asking and discussing during the activity.
\end{abstract}

\begin{tabular}{l}
\hline Artikel Info \\
Sejarah Artikel \\
Diterima: $2020-11-17$ \\
Direvisi: $2021-01-05$ \\
Dipublikasi: $2021-01-13$
\end{tabular}

Kata kunci: Digital Literasi; Belajar dari Rumah; Orang tua.

\begin{abstract}
Abstrak
Kemajuan teknologi yang berkembang pesat berpengaruh terhadap kehidupan seharihari. Di era digital ini, beragam pengetahuan sudah dapat dicari di internet. Dengan kondisi saat ini dimana internet bukan lagi sesuatu yang mahal, tentu saja memaksa orang tua untuk ikut mengikuti perkembangan zaman. Karena itu, tujuan dari kegiatan ini adalah untuk memberikan pengetahuan kepada orang tua/wali murid terhadap pengertian dan pengimplementasiaqn Digital Literacy dalam kondisi belajar dari rumah (BDR). Kegiatan ini berfokus untuk memberikan sosialisasi tentang pentingnya pemahaman serta pelaksanaan pendampingan anak-anak di rumah menggunakan teknologi. Metode yang digunakan dalam kegiatan ini adalah metode ceramah, simulasi, dan praktek. Para peserta memberikan respon positif terhadap kegiatan ini, yang dapat dilihat dari hasil angket di akhir pelatihan. Selain itu hal tersebut juga dapat dilihat dari antusiasme peserta dalam kegiatan dengan aktif bertanya dan berdiskusi selama kegiatan berlangsung.
\end{abstract}

\section{PENDAHULUAN}

Pandemi Covid-19 memaksa proses pembelajaran di Indonesia yang biasanya terjadi di dalam kelas atau tatap muka, sekarang harus beralih ke pembelajaran daring (Putri \& Utami, 2020). Peran guru sebagai orang tua kedua yang membantu memberikan pengetahuan secara langsung tidak dapat lagi dilakukan. Anak-anak yang umumnya masuk dan belajar di sekolah mau tak mau harus belajar di rumah. Mereka harus belajar secara mandiri agar tidak tertinggal jauh selama pandemi ini masih berlangsung.

Perubahan yang signifikan tidak hanya dirasakan oleh para siswa dan guru di sekolah, namun juga oleh orangtua atau wali dari siswa itu sendiri (Duraku \& Hoxha, 2020). Orangtua/wali mau tidak mau harus membimbing putra/putrinya belajar di rumah. Dengan peralatan dan pengetahuan seadanya, orangtua/wali siswa harus dapat menyisihkan waktu dan tenaganya untuk dapat membimbing putra- putrinya di rumah. Pekerjaan dan kesibukan mereka pun harus dapat mereka tunda agar anak-anaknya dapat terus mengikuti pembelajaran.

Ketidaksiapan orang tua dalam mengawasi proses pembelajaran jarak jauh anak menjadi sebuah kendala yang terjadi saat ini (Mansyur, 2020). Tidak dapat dipungkiri, kebanyakan dari orang tua atau wali siswa dalam pembelajaran jarak jauh masih kesulitan dalam teknologi yang digunakan. Tidak banyak orangtua atau wali siswa yang masih tertinggal dalam hal teknologi sehingga mereka pun tidak mengerti apa yang harus dilakukan. Faktor lain yang menjadi sorotan, adalah orangtua/wali yang memiliki kesibukan terhadap pekerjaanya. Mereka tidak hanya harus mendampingi putra/putrinya, namun mereka juga harus tetap menjalankan pekerjaanya, demi tetap menghidupi keluarga mereka. Hal ini mengakibatkan orangtua atau wali yang tidak memiliki waktu yang cukup untuk membimbing putra-putrinya dalam pembelajaran jarak jauh. 
Salah satu hal yang menjadi kendala adalah perbedaan pemahaman antara orang tua dan anak mengenai konsep literasi digital. Menurut Setyaningsih dkk (2019) literasi digital adalah tingkat ketertarikan, sikap dan kemampuan seseorang dalam penggunaan teknologi dan alat komunikasi digital. Anak yang teridentifikasi sebagai generasi abad 21 atau yang biasa disebut dengan digital native adalah generasi yang peka terhadap teknologi informasi yang dimana kemampuannya dalam menggunakan teknologi jauh di atas generasi pendatang digital. Menurut Pendit (2013) terdapat kesenjangan antara bagaimana persepsi hingga kemampuan orang tua yang dimana adalah notabene para generasi imigran digital dengan anak yang termasuk generasi digital native.

Media digital memudahkan siapapun memenuhi aneka kebutuhannya, dari mencari bermacam informasi, bermain (game), berbisnis hingga mencari hiburan. Harga gadget (gawai) sebagai perangkat penerima yang kian ekonomis, pengoperasian yang kian mudah, fitur yang semakin beragam, serta akses internet yang kian mudah dan murah meneguhkan mudahnya menggunakan media digital. Kehadiran teknologi tak mungkin ditolak karena sesungguhnya ia hadir untuk memudahkan dan meningkatkan kesejahteraan manusia. Namun di sisi lain, ada dampak buruk mengancam bila penggunaannya tidak disertai pemahaman yang baik dan sikap bijak. Hal ini tentu menjadi tantangan yang tak bisa diabaikan. Seluruh pihak, pemerintah, lembaga pendidikan dan orang tua.

Davidson (2012) menunjukkan bahwa untuk bisa menggunakan internet dengan positif, anak-anak membutuhkan bimbingan orangtua. Oleh karena itu, untuk dapat melakukan pembimbingan, orangtua dituntut mempunyai kecakapan baik teknis, pengetahuan, maupun emosi dalam mengakses berbagai informasi maupun hiburan melalui internet. Dengan perkataan lain, dalam penggunaan internet oleh anakanak di rumah, bimbingan orangtua sangat diperlukan. Pembimbingan ini merupakan sebuah wujud nyata dari literasi digital yang dapat ditularkan dari orangtua kepada anak-anak, terutama yang berusia di bawah 12 tahun. Pentingnya peran orangtua sebagai pendamping anak dalam menggunakan internet tidak lain karena anak belum mempunyai kecakapan teknis, pengetahuan maupun emosi dalam mengakses berbagai informasi dan hiburan melalui internet.

Melihat kenyataan di atas, perlu dilaksanakannya sebuah program sosialisasi dan pengenalan konsep literasi digital serta bagaimana pengimplementasiannya dalam proses belajar jarak jauh untuk para orangtua masa kini. Program pengabdian masyarakat ini dirasa perlu untuk dilaksanakan untuk meningkatkan pemahaman para orangtua di Indonesia mengenai pentingnya pengawasan orangtua dalam proses belajar jarak jauh. Selain itu juga, pengabdian masyarakat ini bertujuan untuk memberikan contoh pengimplementasian kegiatan pembelajaran yang dapat diaplikasikan di rumah bersama orangtua dan anak dengan memanfaatkan platform teknologi yang ada.

Pemahaman yang dimiliki oleh orangtua masa kini yang dianggap belum dapat mengimbangi kebutuhan yang dimiliki oleh anak yang juga adalah termasuk generasi digital native menjadi dasar permasalahan yang terjadi. Sehingga solusi yang ditawarkan antara lain memberikan sosialisasi mengenai konsep literasi digital serta bagaimana pengaplikasiannya dalam kehidupan sehari-hari. Pelatihan ini dilakukan melalui Zoom dan kanal YouTube sehingga dapat diakses oleh seluruh orangtua yang ada di Indonesia yang mengalami permasalahan akibat kondisi tersebut di atas. Untuk memperoleh hasil yang optimal, perencanaan dari proses sosialisasi ini dibagi menjadi 2 tahapan yaitu (1) tahapan perencanaan kegiatan, dan (2) tahapan pelaksanaan kegiatan.

Pada akhir kegiatan ini diharapkan para peserta yaitu orangtua dari anak generasi digital native dapat meningkatkan pemahamannya mengenai literasi digital dan juga pengimplementasiannya dalam kehidupan sehari-hari. Selain itu juga, kegiatan ini diharapkan dapat memberikan efek baik bagi orangtua sehingga kedepannya para orangtua dapat lebih baik lagi dalam melaksanakan pengasuhan anak terutama dalam kondisi pasca pandemi atau pembelajaran jarak jauh seperti sekarang.

\section{METODE PENELITIAN}

Penelitian ini dilakukan dengan Metode ceramah untuk memberikan materi tentang Digital Parenting dan Digital Literacy serta perkembangan orang tua dan anak di era digital, selain itu Metode simulasi juga dilakukan untuk memberikan tentang langkahlangkah pengasuhan anak di era digital dengan tujuan bagaimana mengasuh anak dengan memahami dan menerima perkembangan teknologi yang juga mempengaruhi hidup anak. dalam implementasinya penelitian ini terdiri atas 98 orang tua di Indonesia yang melakukan praktik secara mandiri dalam penerapan pengasuhan anak secara digital. Adapun waktu Kegiatan yang dimaksud terlaksana pada bulan September tahun 2020, dimana narasumber dan peserta kegiatan mengikuti secara daring dari tempat masing-masing melalui Zoom dan YouTube.

\section{HASIL DAN PEMBAHASAN}

\section{A. Hasil Penelitian}

Pendekatan yang dilakukan kepada orang tua yang tergabung dalam komunitas Relawan TIK Provinsi Bali untuk mengetahui permasalahan yang dialami oleh orang tua atau wali terhadap proses pembelajaran jarak jauh. Serta Koordinasi ke komunitas Relawan Prov Bali mengenai teknis pelaksanaan pelatihan dan sosialisasi sehingga terpilihnya platform Youtube dan Zoom sebagai media pelaksanaan kegiatan. Adapun pelaksanaan dari Kegiatan ini difokuskan pada anak-anak agar dapat menggunakan teknologi secara positif. 
Sebagai pembuka, disajikan perbedaan antara generasi digital immigrant dan generasi digital native. Selanjutnya, diberikan tips untuk mewujudkan generasi digital native Indonesia agar dapat menjadi productive digital citizens masa depan. Setelah itu, peserta kegiatan menyimak simulasi penggunaan aplikasi atau website untuk membantu pembelajaran anak-anaknya yang nantinya para peserta dapat melakukan praktik secara mandiri.

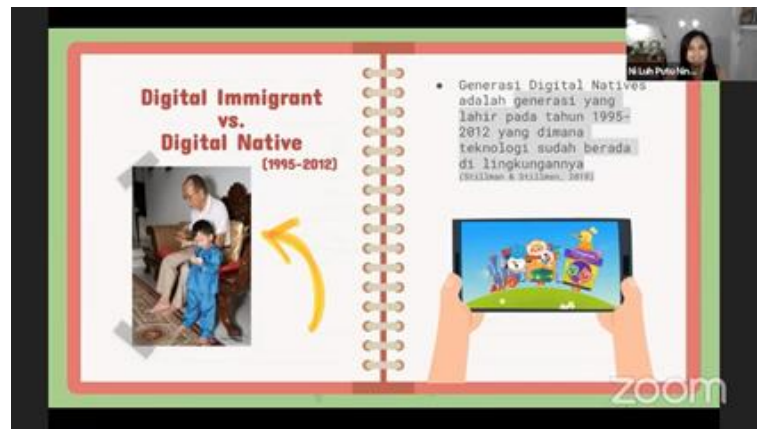

Gambar 1. Pemaparan materi perbedaan generasi digital immigrant dan digital native

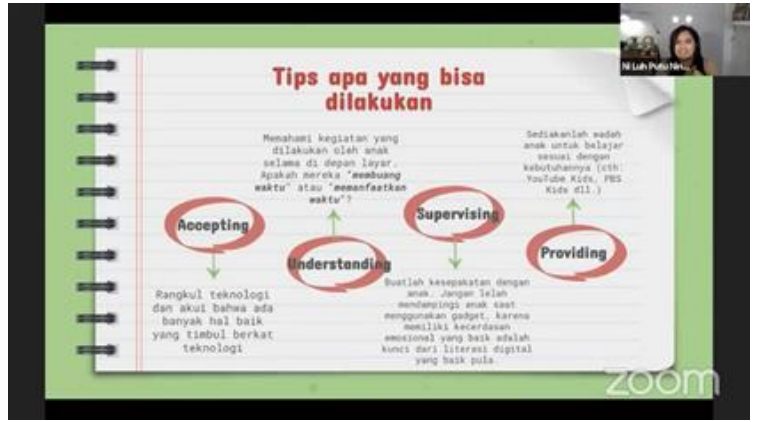

Gambar 2. Pemberian tips mewujudkan generasi digital native

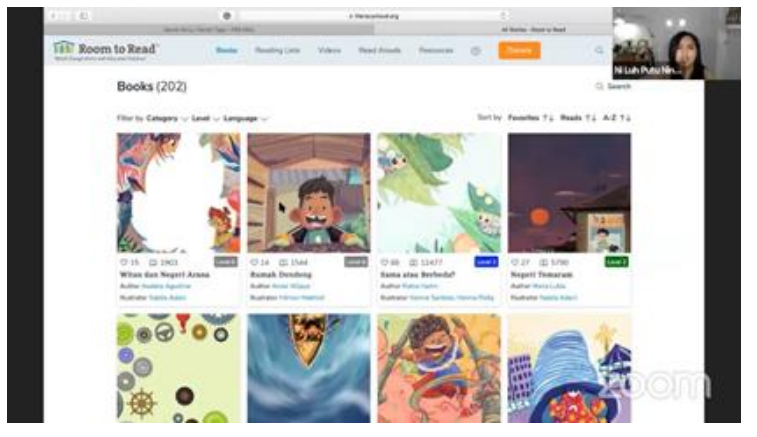

Gambar 3. Simulasi penggunaan website pembelajaran

\section{B. Pembahasan}

Kegiatan ini memberikan pemahaman bagi orang tua khususnya dalam hal Digital Literacy. Para orang tua dapat memahami bagaimana cara mendidik dan memahami anak-anaknya di tengah arus perkembangan teknologi. Kegiatan ini pun berlangsung sangat baik, dimana antusiasme para orang tua sangat tinggi terutama dalam memahami teknologi untuk membantu proses belajar anakanaknya di tengah pandemi. Hal ini juga dapat dilihat dari hasil angket yang diberikan di akhir pembelajaran, menyatakan respon positif dari para peserta pelatihan.

Dalam kegiatan ini diharapkan agar peserta kegiatan dapat mengikuti perkembangan teknologi, terutama dalam penggunaan website dan aplikasi yang membantu proses pembelajaran anak-anak. Selain itu, kedepannya diharapkan kegiatan seperti ini semakin membantu orang tua dalam mendampingi kegiatan belajar anak terutama dengan menggunakan platform digital yang baik untuk pendidikan dan tumbuh kembang anak.

\section{KESIMPULAN DAN SARAN}

Kegiatan ini telah terlaksana dengan baik. Para peserta yang terdiri dari orang tua dan wali murid mampu mengikuti dan menyimak materi yang dibawakan. Respon dari para peserta dalam kegiatan ini pun sangat baik, dimana dapat dilihat dari antusiasme para peserta selama kegiatan berlangsung. Peserta terlihat sangat aktif baik dalam sesi penyampaian materi, diskusi, hingga sesi tanya jawab. Kegiatan juga ini mendapat respon yang positif yang dapat terlihat dari hasil angket peserta di akhir kegiatan. Untuk selanjutnya, diharapkan agar kegiatan-kegiatan seperti ini akan lebih sering diadakan terutama untuk pengembangan proses pendidikan bagi anak-anak yang terdampak pandemi. Penulis juga berharap agar orang tua selalu dapat mendampingi anak-anaknya dalam proses belajar dari rumah agar dapat semakin meningkatkan kualitas pendidikan di Indonesia terutama di saat pandemi seperti saat ini.

\section{DAFTAR RUJUKAN}

Davidson, C. (2012). Seeking the green basilisk lizard: Acquiring digital literacy practices in the home. Journal of Early Childhood Literacy, Vol. 12. No. 1: $24-45$.

Duraku, Z. H., \& Hoxha, N. (2020). The impact of COVID-19, school closure, and social isolation on gifted students' wellbeing and attitudes toward remote (online) learning. Retrieved from:

https://www.researchgate.net/publication/34 1297812 The impact of COVID-

19 on education and on the well-

being of teachers parents and students Chall enges related to remote online learning and opportunities for advancing the quality of ed ucation

Fathirma'ruf, F., \& M. Said, B. (2020). Pengembangan Perangkat Pembelajaran Konstruktivistik Model Teaching with Analogies (TWA) pada Mata Kuliah Database Management System 
(DBMS) untuk Meningkatkan Kemampuan Berpikir Kreatif Mahasiwa. Jurnal Teknologi Informasi dan Ilmu Komputer, 7(5), 1051-1060. doi:http://dx.doi.org/10.25126/jtiik.2020752 388

Mansyur, A. R. (2020). Dampak COVID-19 Terhadap Dinamika Pembelajaran Di Indonesia. Education and Learning Journal, 1, 113-123.

Pendit, P. L. (2013). Digital native, literasi informasi dan media digital-Sisi pandang kepustakawanan". In Seminar Dan Lokakarya Perubahan Paradigma Digital Natives
Perpustakaan Universitas.

Putri, N. L. P. N. S., \& Utami, N. W. (2020). Pelatihan Pembuatan Buku Cerita Digital Sederhana Sebagai Bahan Ajar dalam Kondisi New Normal. Jurnal Karya Abdi Masyarakat, 4(1), 143-147.

Setyaningsih, R., Abdullah, A., Prihantoro, E., \& Hustinawaty, H. (2019). Model penguatan literasi digital melalui pemanfaatan e-learning. Jurnal ASPIKOM, 3(6), 1200-1214. 